\title{
Resident Involvement and Participation in Urban Tourism Development: A Comparative Study in Maun and Gaborone, Botswana
}

\author{
Naomi Moswete $\cdot$ Elisha N. Toteng • \\ Joseph E. Mbaiwa
}

Published online: 6 January 2009

(C) Springer Science + Business Media B.V. 2008

\section{Erratum to: Urban Forum}

DOI 10.1007/s12132-008-9041-x

After publication of this article, it has been discovered that Brijesh Thapa is Naomi Moswete's academic advisor and therefore erroneously mentioned as second author. We sincerely apologize for this.

The online version of the original article can be found at http://dx.doi.org/10.1007/s12132-008-9041-x.

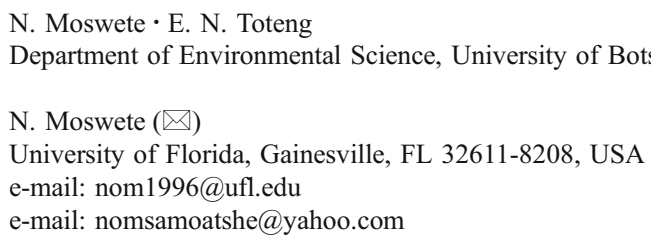

